\title{
CD109 wt Allele
}

National Cancer Institute

\section{Source}

National Cancer Institute. CD109 wt Allele. NCI Thesaurus. Code C102949.

Human CD109 wild-type allele is located in the vicinity of $6 q 13$ and is approximately 133

kb in length. This allele, which encodes CD109 antigen protein, may play a role in the modulation of both proteolysis and signaling. 